$$
\text { CONF-970443--4 }
$$

\title{
Biodesulfurization of Flue Gases using Synthesis Gas Delivered as Microbubbles*
}

\author{
Punjai T. Selvaraj**, Marshall D. Bredwell, \\ Mark H. Little, and Eric N. Kaufman \\ Bioprocessing Research and Development Center \\ Oak Ridge National Laboratory \\ Bldg. 4505, MS 6226 \\ Oak Ridge, Tennessee 37831-6226 \\ 423-574-6786; vpj@ornl.gov \\ RECEIVED \\ JAN 2819997 \\ OS TI
}

Submitted as a preprint to American Chemical Society Spring 1997 Symposium

"The submitted manuscript has been authored by a contractor of the U.S. Government under contract DE-AC05-96OR22464. Accordingly, the U.S. Government retains a nonexclusive, royalty-free license to publish or reproduce the published form of this contribution, or allow others to do so, for U.S. Government purposes."

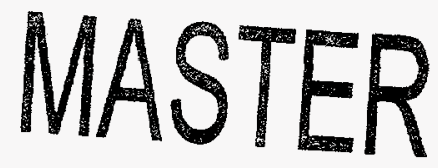

NSTREUTION OF THS DOOUnT IS UMIMIED

* Research supported by the Advanced Research and Technology Development Program of the Office of Fossil Energy, U.S. Department of Energy under contract DE-AC05-96OR22464 with Lockheed Martin Energy Research Corp.

** To whom all correspondence should be addressed. 


\section{DISCLAMMER}

Portions of this document may be illegible. in electronic image produets. Images are produced from the best available original document. 


\title{
BIODESULFURIZATION OF FLUE GASES USING SYNTHESIS GAS DELIVERED AS MICROBUBBLES
}

\author{
Punjai T. Selvaraj**, Marshall D. Bredwell, \\ Mark H. Little, and Eric N. Kaufman \\ Bioprocessing Research and Development Center \\ Oak Ridge National Laboratory \\ Bldg. 4505, MS 6226 \\ Oak Ridge, Tennessee 37831-6226
}

Keywords: Biodesulfurization, synthesis gas, microbubbles

\section{Introduction}

Anaerobic treatment processes for biodegradation of hazardous materials have increasingly been gaining attention in environmental applications. Microbial processes utilizing sulfate reducing bacteria (SRB), in particular, have found potential applications in variety of treatment processes such as flue gas desulfurization [1,2], gypsum reclamation [3], sulfur recovery from sulfite/sulfate wastewater from pulp and paper, chemical and mining industries [4], and degrading explosive materials [5]. However, in all these applications, the source of electron donor is a major factor on the economics of the process. Previously, we have proposed a microbial process with sewage digest as an attractive low-cost feedstock for SRB cultures in the desulfurization of flue gases and sulfite/sulfate-laden industrial waste water [6]. In that process, a columnar reactor with mixed SRB cultures immobilized in BIO-SEP ${ }^{\mathrm{TM}}$ polymeric porous beads with sewage digest as a carbon and energy source exhibited conversion rate of $16.5 \mathrm{mmol}$ sulfite/h.L $\left(32 \mathrm{~kg} / \mathrm{d} \bullet \mathrm{m}^{3}\right)$ with $100 \%$ conversion to $\mathrm{H}_{2} \mathrm{~S}$. Though municipal sewage digest is a readily available low-cost carbon source, the real cost of the medium depends on the location of the sewage treatment plant and power plant and on the transportation involved in bringing the sewage back and forth from the sewage plant. Therefore, the current research has been focused on an alternative low-cost feedstock. Various groups have demonstrated that SRB could be supported by carbon dioxide and/or carbon monoxide as the sole carbon source and hydrogen as the energy source [7-11]. Du Preez et al. $[8,10]$ operated a sulfate-reducing reactor with a mixed SRB population to demonstrate the feasibility of using syn-gas as the feed source for SRB. Recently, van Houten et al. [9] reported the operation of a gas-lift sulfate-reducing reactor that was fed a CO- $\mathrm{H}_{2}$ mixture (up to $20 \%$ $\mathrm{CO}$ ) and yielded a maximum sulfate conversion rate of $30 \mathrm{~g} \mathrm{SO}_{4}{ }^{2-} / \mathrm{d} \cdot \mathrm{L}$.

In our study, we have focused our research on utilizing gas mixture containing $36 \% \mathrm{H}_{2}, 47 \% \mathrm{CO}, 10 \% \mathrm{CO}_{2}, 5 \% \mathrm{CH}_{4}$ and balance $\mathrm{N}_{2}$ as a model coal synthesis gas as a low-cost feedstock. This composition is typical of an oxygen blown, coal fed gasifier. Coal synthesis gas will be readily available in power plants and the biological utilization of syn-gas as a carbon and energy source produces no organic end product that has to be processed prior to its disposal. Coal synthesis gas is, however, sparingly soluble in aqueous phase. Our process utilizing SRB with syn-gas feedstock may be mass transfer limited and methods to enhance the mass transport have been investigated. A CSTR with 
cell recycle and a trickle bed reactor with cells immobilized in BIO-SEP ${ }^{\mathrm{TM}}$ polymeric beads were operated with syn-gas feedstock to obtain maximum productivity for $\mathrm{SO}_{2}$ reduction to $\mathrm{H}_{2} \mathrm{~S}$. The CSTR reactor was then fed with syn-gas as microbubbles in an effort to improve the mass transfer properties.

\section{Materials and Methods}

\section{Microbial Culture and Media}

Mixed SRB cultures were originally isolated from sewage solids obtained from the DAF unit of a municipal sewage treatment plant at Oak Ridge, TN. The cultures were grown in lactic acid media (LA) which consists of $3.6 \mathrm{~g} / \mathrm{L}$ citric acid, $0.8 \mathrm{~g} / \mathrm{L} \mathrm{CaCl}, 1.0$ $\mathrm{g} / \mathrm{L} \mathrm{NH}_{4} \mathrm{Cl}, 0.5 \mathrm{~g} / \mathrm{L} \mathrm{K}_{2} \mathrm{HPO}_{4}, 1.0 \mathrm{~g} / \mathrm{L}$ yeast extract, $0.52 \mathrm{~g} / \mathrm{L} \mathrm{FeCl}_{2}, 5.8 \mathrm{~mL} / \mathrm{L}$ of sodium lactate (60\% syrup), $0.518 \mathrm{~mL} / \mathrm{L}$ butyric acid, and $0.05 \mathrm{~g} / \mathrm{L}$ cysteine $\mathrm{HCL}$. A minimal salts media (MS) was also used; $1.2 \mathrm{~g} / \mathrm{L} \mathrm{Na} \mathrm{NPO}_{4}, 1.8 \mathrm{~g} / \mathrm{L} \mathrm{KH}_{2} \mathrm{PO}_{4}, 0.7 \mathrm{~g} / \mathrm{L} \mathrm{MgCl}_{2}, 0.2 \mathrm{~g} / \mathrm{L}$ $\mathrm{NH}_{4} \mathrm{Cl}, 0.04 \mathrm{~g} / \mathrm{L} \mathrm{FeCl}, 50 \mathrm{~mL} / \mathrm{L}$ mineral water, $0.2 \mathrm{~mL} / \mathrm{L}$ Batch vitamin solution, and 15 $\mathrm{mL} / \mathrm{L}$ heavy metal solution (HMS). The Batch vitamin solution contains the following: 2.0 $\mathrm{mg} / \mathrm{L}$ biotin, $2.0 \mathrm{mg} / \mathrm{L}$ folic acid, $10.0 \mathrm{mg} / \mathrm{L}$ pyridoxine hydrochloride, $5.0 \mathrm{mg} / \mathrm{L}$ thiamine hydrochloride, $5.0 \mathrm{mg} / \mathrm{L}$ riboflavin, $5.0 \mathrm{mg} / \mathrm{L}$ nicotinic acid, $5.0 \mathrm{mg} / \mathrm{L}$ DL-calcium pantothenate, $0.1 \mathrm{mg} / \mathrm{L}$ vitamin $\mathrm{B}-12,5.0 \mathrm{mg} / \mathrm{L}$ p-amino benzoic acid, and $5.0 \mathrm{mg} / \mathrm{L}$ lipoic acid. The HMS solution contains the following: $1.5 \mathrm{~g} / \mathrm{L}$ EDTA, $0.1 \mathrm{~g} / \mathrm{L} \mathrm{ZnSO}_{4} \bullet 7 \mathrm{H}_{2} \mathrm{O}$ and $6 \mathrm{~mL} / \mathrm{L}$ of a trace element solution $(0.0507 \mathrm{~g} / \mathrm{L} \mathrm{AlCl}, 0.139 \mathrm{~g} / \mathrm{L} \mathrm{KI}, 0.139 \mathrm{~g} / \mathrm{L} \mathrm{KBr}$, $0.139 \mathrm{~g} / \mathrm{L} \mathrm{LiCl}, 3.060 \mathrm{~g} / \mathrm{L} \mathrm{H}_{3} \mathrm{BO}_{3}, 0.280 \mathrm{~g} / \mathrm{L} \mathrm{ZnCl}, 0.326 \mathrm{~g} / \mathrm{L} \mathrm{CuCl} \mathrm{Zn}_{2} \cdot 2 \mathrm{H}_{2} \mathrm{O}, 0.513 \mathrm{~g} / \mathrm{L}$ $\mathrm{NiCl}_{2} \cdot 6 \mathrm{H}_{2} \mathrm{O}, 0.513 \mathrm{~g} / \mathrm{L} \mathrm{CoCl}_{2} \cdot 6 \mathrm{H}_{2} \mathrm{O}, 0.139 \mathrm{~g} / \mathrm{L} \mathrm{SnCl}_{2} \cdot 2 \mathrm{H}_{2} \mathrm{O}, 0.163 \mathrm{~g} / \mathrm{L} \mathrm{BaCl} \mathrm{Bl}_{2} \cdot 2 \mathrm{H}_{2} \mathrm{O}$, $0.139 \mathrm{~g} / \mathrm{L} \mathrm{Na} \mathrm{MoO}_{4} \cdot 2 \mathrm{H}_{2} \mathrm{O}, 0.139 \mathrm{~g} / \mathrm{L} \mathrm{CuSeO}_{4} \cdot 5 \mathrm{H}_{2} \mathrm{O}$, and $0.024 \mathrm{~g} / \mathrm{L} \mathrm{NaVO}_{3}$ ).

In serum bottles, the sulfate source was provided by the addition of up to $4.0 \mathrm{~g} / \mathrm{L}$ of $\mathrm{Na}_{2} \mathrm{SO}_{4}$ or $\mathrm{MgSO}_{4}$. In the reactors, the sulfite source was provided by a gas mixture containing $5 \% \mathrm{SO}_{2}, 5 \% \mathrm{CO} 2$, and balance $\mathrm{N} 2$. For growth on synthesis gas, a mixture of $47 \% \mathrm{CO}, 36 \% \mathrm{H}_{2}, 10 \% \mathrm{CO}_{2}, 5 \% \mathrm{CH}_{4}$, and the balance $\mathrm{N}_{2}$ was used. For serum bottle studies, $100 \mathrm{~mL}$ of MS media was put into a $-150 \mathrm{~mL}$ bottle and sealed with butyl rubber stopper. A nitrogen headspace was placed on top of the media and the bottles were sterilized by steam. When inoculated from an actively growing culture in a $2 \mathrm{~L}$ chemostat, synthesis gas was bubbled through the culture. The headspace was monitored for synthesis gas components and hydrogen sulfide and was replenished with fresh synthesis gas when needed. The bottles were usually shaken at $100 \mathrm{rpm}$ at $30^{\circ} \mathrm{C}$.

\section{Syn-Gas Utilization by Mixed SRB}

Utilization of syn-gas by mixed SRB culture developed from municipal sewage was investigated in a serum bottle containing minimal salt medium and $\mathrm{SO}_{2}$ as terminal electron acceptor. The head space of the bottle was then filled with synthesis gas mixture containing $36 \% \mathrm{H}_{2}, 47 \% \mathrm{CO}, 10 \% \mathrm{CO}_{2}, 5 \% \mathrm{CH}_{4}$, and balance $\mathrm{N}_{2}$. The bottle was inoculated with mixed SRB culture and incubated at $30^{\circ} \mathrm{C}$ with shaking at $200 \mathrm{rpm}$. The syn-gas concentration was then regularly monitored using a Gas Chromatograph as described below. 
Microbubbles are small, surfactant coated bubbles of gas that are generated by creating a gas-liquid interface in a high-shear zone. The bubbles are between $50 \mu \mathrm{m}$ and $100 \mu \mathrm{m}$ in diameter and the surfactant coating helps to prevent coalescence by electrostatic repulsion from the diffuse electric double layer around the bubble. In our work, the microbubble dispersions were generated using a spinning disk apparatus first described by Sebba [12]. This microbubble generator (MBG) uses a high speed motor (Talboys \#37830, Cole Parmer, Chicago, IL) that spins a $4 \mathrm{~cm}$ disk as speeds above 4000 RPM in close proximity to baffles (within $3 \mathrm{~mm}$ ) to generate a localized high-shear zone. The stainless steel disk and baffles are mounted in $4 \mathrm{~L}$ glass vessel with a ground glass lip to fit the headplate. A second headplate mounted above the first supports the motor and allows easy alignment. Stainless steel sealed bearings insure minimal wobble.

The bubble size measurements were performed on a Coulter LS 130 particle size analyzer (Coulter) using laser diffraction. The microbubble foam sample was loaded into both the constant volume module and hazardous fluids module for the instrument. The constant volume module could contain $15 \mathrm{~mL}$ of sample and had a magnetic stirrer in the bottom of the cell to maintain a well-mixed system. The hazardous fluids module used a recirculating pump. Dispersion was added to water in each module until $8 \%$ to $12 \%$ obscuration was obtained. Data was collected for ninety seconds in each case. Between runs the constant volume module was rinsed with double distilled water and the hazardous fluids modules had the recirculating liquid drained, refilled, and filtered.

\section{CSTR and Trickle Bed Reactors}

A 2 L Virtis Omni-culture chemostat (Virtis Co., Gardiner, NY) with temperature and agitation control was used as the primary reactor vessel. The vessel headplate was modified for acid/base additions and gas and liquid inlets and outlets. The $\mathrm{pH}$ was controlled at 6.8 with a Chemcadet controller with $6 \mathrm{~N} \mathrm{NaOH}$ and $6 \mathrm{~N} \mathrm{H}_{3} \mathrm{PO}_{4}$. The reactor was agitated at $250 \mathrm{rpm}$ for all experimental runs. The reactor was operated in a continuous mode with a feed rate of fresh MS medium at $0.2 \mathrm{~mL} / \mathrm{min}$. To retain biomass in the reactor, a filtration system consisted of two Amicon Diaflo hollow fiber cartridges was attached to the reactor. All pumps used were Masterflex peristaltic. A sparge of 50 $\mathrm{mL} / \mathrm{min}$ of nitrogen was added to the reactor vessel to strip off the produced $\mathrm{H}_{2} \mathrm{~S}$ from the reactor. The synthesis gas was fed directly at a rate of $10 \mathrm{~mL} / \mathrm{min}$ to the reactor during the control runs through a stainless steel sparger. The flow rate of $\mathrm{SO}_{2}$ gas fed separately into the reactor was monitored using gas flow meter. In the microbubble-fed system, the permeate from the filters was returned to the MBG. the syn-gas microbubbles were generated by bubbling syn-gas into minimal salt medium containing Tween-20 as surfactant. The microbubbles were then fed to the CSTR at a rate of $15 \mathrm{~mL} / \mathrm{min}$. which was equivalent to $10 \mathrm{~mL} / \mathrm{min}$ of synthesis gas as fed during the control run.

The trickle bed reactor consisted of fully jacketed glass column of internal dimensions $2.5 \times 30 \mathrm{~cm}$ with a total volume of $180 \mathrm{~mL}$ and a working volume of $81 \mathrm{~mL}$ with BIO-SEP ${ }^{\mathrm{TM}}$ beads. BIO-SEP ${ }^{\mathrm{TM}}$ beads, encapsulated activated carbon $(50-80 \%)$ in aromatic polyamide (Aramid) (20-50\%) were obtained as the kind gift of Dr. Carl Camp from the DuPont Chemical Co. (Glasgow, DE). A $500 \mathrm{~mL}$ bottle with a specially made headplate was used for $\mathrm{pH}$ control, $\mathrm{H}_{2} \mathrm{~S}$ stripping by nitrogen, gas outlet, and ports for continuous operation. The reactor had biomass loaded on to the BIO-SEP beads by 
operation in a packed bed mode on lactate media. The liquid inside of the reactor was completely recycled. When switched to a synthesis gas feed, the reactor was operated in a trickle bed mode with the liquid and both gas feeds entering at the top of the reactor. Gas samples were taken from a gas disengagement bottle. The reactor was operated in a continuous mode with a fresh minimal salt medium at a feed rate of $12 \mathrm{~mL} / \mathrm{h}$. In trickle bed mode, the liquid flow rate across the bed was $600 \mathrm{~mL} / \mathrm{h}$.

In all runs the reactor was monitored for sulfite. The off-gas from the reactor was also monitored for $\mathrm{H}_{2} \mathrm{~S}$ and synthesis gas components. The off-gas flow rates were monitored with a wet test meter for two hour periods.

\section{Analytical}

The sulfite in the reactor was analyzed spectrophotometrically by the reaction of fuchsin and formaldehyde in sulfuric acid [13]. The sulfide in the reactor was precipitated using zinc acetate in a basic solution followed by resuspension and measurement using the formation of methylene blue [14].

Hydrogen sulfide in the off gas was analyzed using a gas chromatograph (Hewlett Packard HP 5890 Series II) equipped with a teflon column (30 in $\times 1 / 8$ in) packed with Super Q (80/100 mesh) (Alltech, Waukeegen, WI). Temperatures of the column, injection port, and thermal conductivity detector were $70{ }^{\circ} \mathrm{C}, 125^{\circ} \mathrm{C}$, and $125^{\circ} \mathrm{C}$ respectively. The carrier gas was helium at $25 \mathrm{~mL} / \mathrm{min}$. The calibration was based on $1 \%, 5 \%$, and $10 \% \mathrm{H}_{2} \mathrm{~S}$ in nitrogen standards. Synthesis gas components were measured using a gas chromatograph (Hewlett Packard HP 5890 Series II) equipped with a HP PLOT molecular sieve $5 \AA$ capillary column $(30 \mathrm{~m} \mathrm{x} 0.32 \mathrm{~mm}$ ) with a $12 \mu \mathrm{m}$ film thickness. Temperatures on the column, injection port, and thermal conductivity detector were 55 ${ }^{\circ} \mathrm{C}, 100{ }^{\circ} \mathrm{C}$, and $240{ }^{\circ} \mathrm{C}$ respectively. Liquid samples were filtered through a $0.22 \mu \mathrm{m}$ syringe filter and analyzed by gas chromatography using a HP 5890 Series II with a HP WAT (crosslinked PEG) capillary column $(30 \mathrm{~m} \times 0.53 \mathrm{~mm})$ with a $1.0 \mu \mathrm{m}$ film thickness. The column temperature program was initially $70{ }^{\circ} \mathrm{C}$ followed by ramping to $200{ }^{\circ} \mathrm{C}$ at 25 ${ }^{\circ} \mathrm{C} / \mathrm{min}$ with a $1.2 \mathrm{~min}$ hold then followed by ramping to $225^{\circ} \mathrm{C}$ at $25^{\circ} \mathrm{C} / \mathrm{min}$ with a 3.0 $\mathrm{min}$ hold. The injection port temperature was $245^{\circ} \mathrm{C}$ while the flame ionization detector was $265^{\circ} \mathrm{C}$.

\section{Results and Discussion Syn-Gas Utilization by Mixed SRB}

The syn gas utilization is shown in Fig. 1. Initially, a decrease in CO concentration was observed with no change in $\mathbf{H}_{2}$ concentration. However, hydrogen sulfide was detected during this time in the head space of the serum bottle. This indicates that the CO was utilized by certain type of bacteria and produced $\mathrm{H}_{2}$ as shown in the equation below:

$$
\mathrm{CO}+\mathrm{H}_{2} \mathrm{O} \quad \rightarrow \quad \mathrm{H}_{2}+\mathrm{CO}_{2}
$$

With limited $\mathrm{SO}_{2}$ reduction due to a possible $\mathrm{CO}$ inhibition at higher concentration, the $\mathrm{H}_{2}$ concentration declined only after the $\mathrm{CO}$ concentration was less than about $5 \%$ in the mixture. This suggests that the mixed culture developed from sewage solids would be 
able to use $\mathrm{CO}$ as sole carbon and energy source and produce $\mathrm{H}_{2}$. Kinetically, the $\mathrm{CO}$ utilization was much faster than $\mathrm{H}_{2}$ utilization by SRB cultures.

Serum bottle experiments with mixed SRB showed that we could switch between lactate and syn-gas for carbon and energy source that would help us to start the reactor operation moe quickly.

\section{CSTR with syn-gas feed}

The CSTR in the control mode in which the syn-gas was fed directly into the reactor was able to convert $1.2 \mathrm{mmol} \mathrm{SO}_{2} / \mathrm{h} \cdot \mathrm{L}$ with no sulfite detected in the effluent (Fig. 2). The off-gas analysis through $\mathrm{GC}$ showed $100 \%$ conversion of $\mathrm{SO}_{2}$ into $\mathrm{H}_{2} \mathrm{~S}$. With continuous $\mathrm{N}_{2}$ purging in the liquid medium, the sulfide concentration in the aqueous phase was measured to be less than $5 \mathrm{mg} / \mathrm{L}$. When the $\mathrm{SO}_{2}$ feed was increased above 1.2 $\mathrm{mmol} / \mathrm{h} \bullet \mathrm{L}$, sulfite accumulation of greater than $25 \mathrm{mg} / \mathrm{L}$ was observed in the reactor medium. This indicated that the reactor reached the maximum productivity of $1.2 \mathrm{mmol}$ $\mathrm{SO}_{2} / \mathrm{h} \cdot \mathrm{L}$ under the operating conditions. The synthesis gas content in the feed and the offgas showed the stoichiometric conversion of $1.8 \mathrm{~mol} \mathrm{H}_{2}$ and $2.3 \mathrm{~mol} \mathrm{CO}$ per mol of $\mathrm{SO}_{2}$. The reactor was then operated at $1.2 \mathrm{mmol} / \mathrm{h} \cdot \mathrm{L}$, for $3 \mathrm{~d}$ and switched over to microbubble-fed system. With syn-gas fed as microbubbles, the $\mathrm{SO}_{2}$ feed rate was increased incrementally and obtained maximum productivity of $2.1 \mathrm{mmol} / \mathrm{h} \cdot \mathrm{L}$ with $100 \%$ conversion to $\mathrm{H}_{2} \mathrm{~S}$ in $33 \mathrm{~h}$. The biomass concentration in the reactor prior to the microbubble operation was $5 \mathrm{~g} / \mathrm{L}$. The increase of productivity from 1.2 to $2.1 \mathrm{mmol} / \mathrm{h} \cdot \mathrm{L}$ within the span of $33 \mathrm{~h}$ at the same biomass concentration of $5 \mathrm{~g} / \mathrm{L}$ indicated that the mass transport of syn-gas was the limiting parameter in the above process.

\section{Trickle-bed reactor with syn-gas feed}

Initially, the immobilization of mixed SRB cells in BIO-SEP beads in a trickle-bed reactor was started-up with lactate medium as described earlier. This was achieved in $14 \mathrm{~d}$. Following the immobilization, the reactor was fed with syn-gas at a rate of 10 $\mathrm{mL} / \mathrm{min}$ as a sole carbon and energy source and $5 \% \mathrm{SO}_{2}$ at rate of $4 \mathrm{~mL} / \mathrm{min}(2.7$ $\mathrm{mmol} / \mathrm{h} \bullet \mathrm{L}$ ). The immobilized SRB cells grown on lactate medium were able to switch to syn-gas at once. The $\mathrm{SO}_{2}$ feed rate was then increased incrementally with no sulfite detected in the effluent. As shown in Fig. 2, complete conversion of $\mathrm{SO}_{2}$ into $\mathrm{H}_{2} \mathrm{~S}$ was achieved at a maximum $\mathrm{SO}_{2}$ feed of $8.8 \mathrm{mmol} / \mathrm{h} \cdot \mathrm{L}$ with syn-gas utilization of $1.0 \mathrm{~mol} \mathrm{H}_{2}$ and $1.2 \mathrm{~mol} \mathrm{CO}$ per mol of $\mathrm{SO}_{2}$. This compares to previous studies which achieved 4.3 mmol $\mathrm{SO}_{4}{ }^{2-} / \mathrm{h} \cdot \mathrm{L}[9]$ and $0.5 \mathrm{mmol} / \mathrm{h} \bullet \mathrm{L}$ [10] with synthesis gas as feedstock.

\section{Conclusion}

The model coal synthesis gas containing $36 \% \mathrm{H}_{2}, 47 \% \mathrm{CO}, 10 \% \mathrm{CO}_{2}, 5 \% \mathrm{CH}_{4}$, and balance $\mathrm{N}_{2}$ has been found as a low-cost feedstock for mixed SRB in the desulfurization processes. With syn-gas fed as microbubbles, productivity in the CSTR increased from 1.2 to $2.1 \mathrm{mmol} / \mathrm{h} \cdot \mathrm{L}$ in $33 \mathrm{~h}$. This has been observed at the same biomass concentration of $5 \mathrm{~g} / \mathrm{L}$. This shows the mass transport limitation in the above process. In the trickle bed reactor, maximum productivity of $8.8 \mathrm{mmol} / \mathrm{h} \cdot \mathrm{L}$ was achieved with less carbon and energy requirement $\left(1 \mathrm{~mol} \mathrm{H}_{2}\right.$ and $1.2 \mathrm{~mol} \mathrm{CO}$ per mol of $\left.\mathrm{SO}_{2}\right)$ indicating better surface to volume ratio with cells immobilized in the pores of polymeric beads. The 
mass transfer coefficients in these systems will be determined in future studies to develop better reactor configuration for biodesulfurization of flue gases and other sulfur wastes.

\section{Acknowledgments}

This work was supported by the Advanced Research and Technology Development Program of the Office of Fossil Energy, U.S. Department of Energy under contract DE-AC05-96OR22464 with Lockheed Martin Energy Research Corp. Material contribution and analytical assistance from the DuPont Chemical Company and the Conoco Company, respectively, are greatly appreciated.

\section{References}

1. Selvaraj, P.T., and Sublette, K.L. (1995), Biotechnol. Prog. 11, 153-158.1.

2. Paques B.V. and Hoogovens Technical Services (1995), Bio-technological Flue Gas Desulfurization Report.

3. Kaufman, E.N., Little, M.H., and Selvaraj, P.T. (1996), J. Chem. Technol. Biotechnol. 66, 365-374.

4. Hammack, R.W., Edenborn, H.M., and Dvorak, D.H. (1994), Water Res. 28, 11, 2321-2329.

5. Boopathy, R., and Manninig, J.F. (1996), American Academy of Environmental Engineers, Washington DC. pp 61-75.

6. Selvaraj, P.T., Little, M.H., and Kaufman, E.N. (1996), submitted to Bioremediation.

7. van Houten, R.T., Pol, L.W.H., and Lettinga, G. (1994), Biotechnol. Bioeng. 44, 586-594.

8. Du Preez, L.A., Odendaal, J.P., Maree, J.P., and Posonby, M. (1992), Environ. Technol. 13, 875-882.

9. van Houten R.T., van der Spoel, H., van Aelst, A.C., Hulshoff Pol, L.W., and Lettinga, G. (1996), Biotechnol. Bioeng. 50, 136-144.

10. Du Preez, and Maree, J.P., (1992), Water Sci. Tech. 30, 275-285.

11. Kaufman, E.N., Little, M.H., and Selvaraj, P.T. (1996), Appl. Biochem. Biotechnol. (in press).

12. Sebba, F. (1985), Chemistry and Industry, 91-92.

13. Steigman, A. (1950), Anal. Chem. 22, 492-493.

14. Tanner, R. S. (1989), J. Microbiological Methods. 


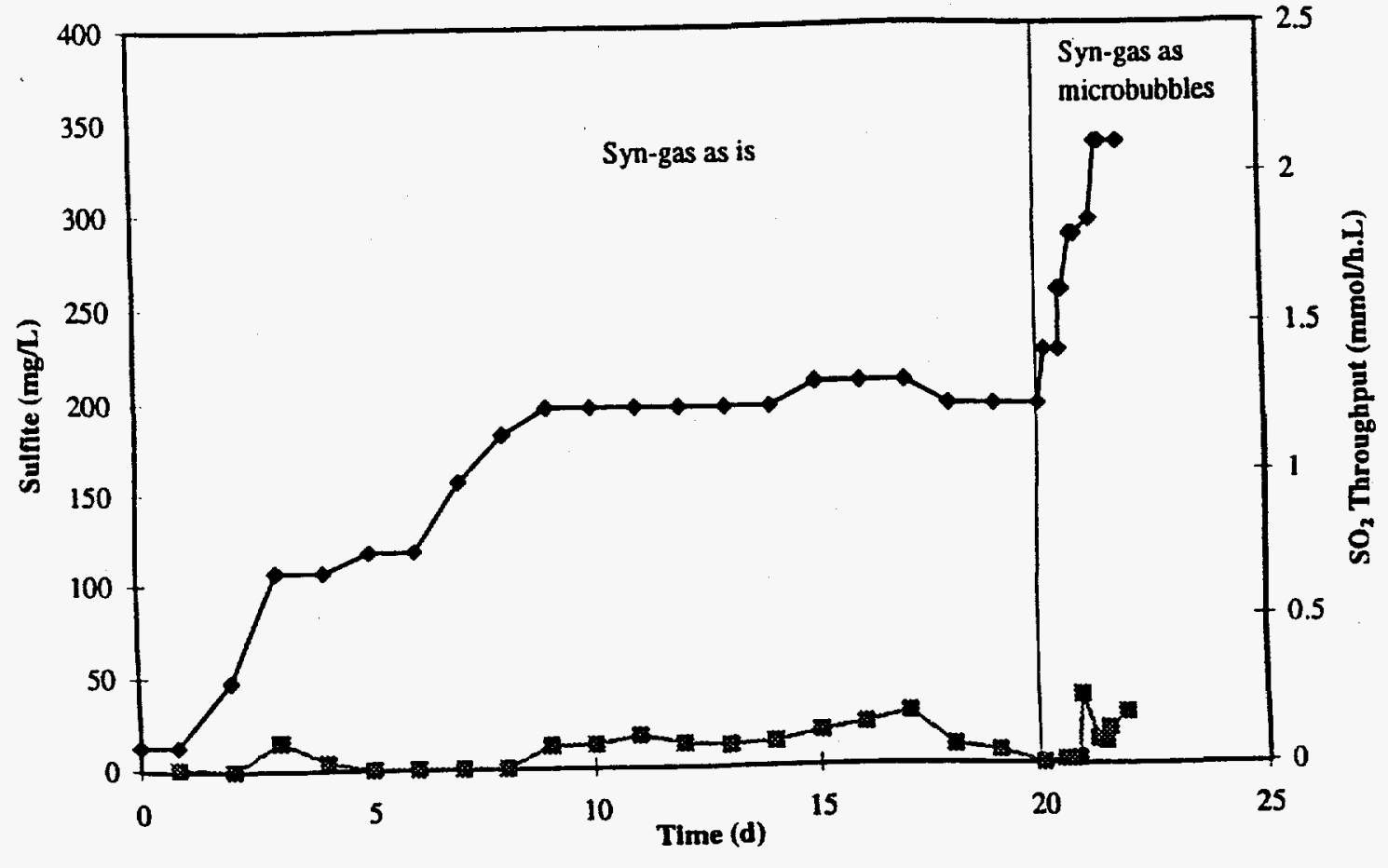

$\rightarrow-$ Effluent Sulfite (mg/L) $\rightarrow$ SO2 Throughput (mmol/h.L)

Figure 1. Sulfite conversion in a CSTR with syn-gas as feedstock. With syn-gas fed as microbubbles, the reactor productivity was increased from 1.2 to $2.1 \mathrm{mmol} / \mathrm{h} . \mathrm{L}$ in $33 \mathrm{~h}$.

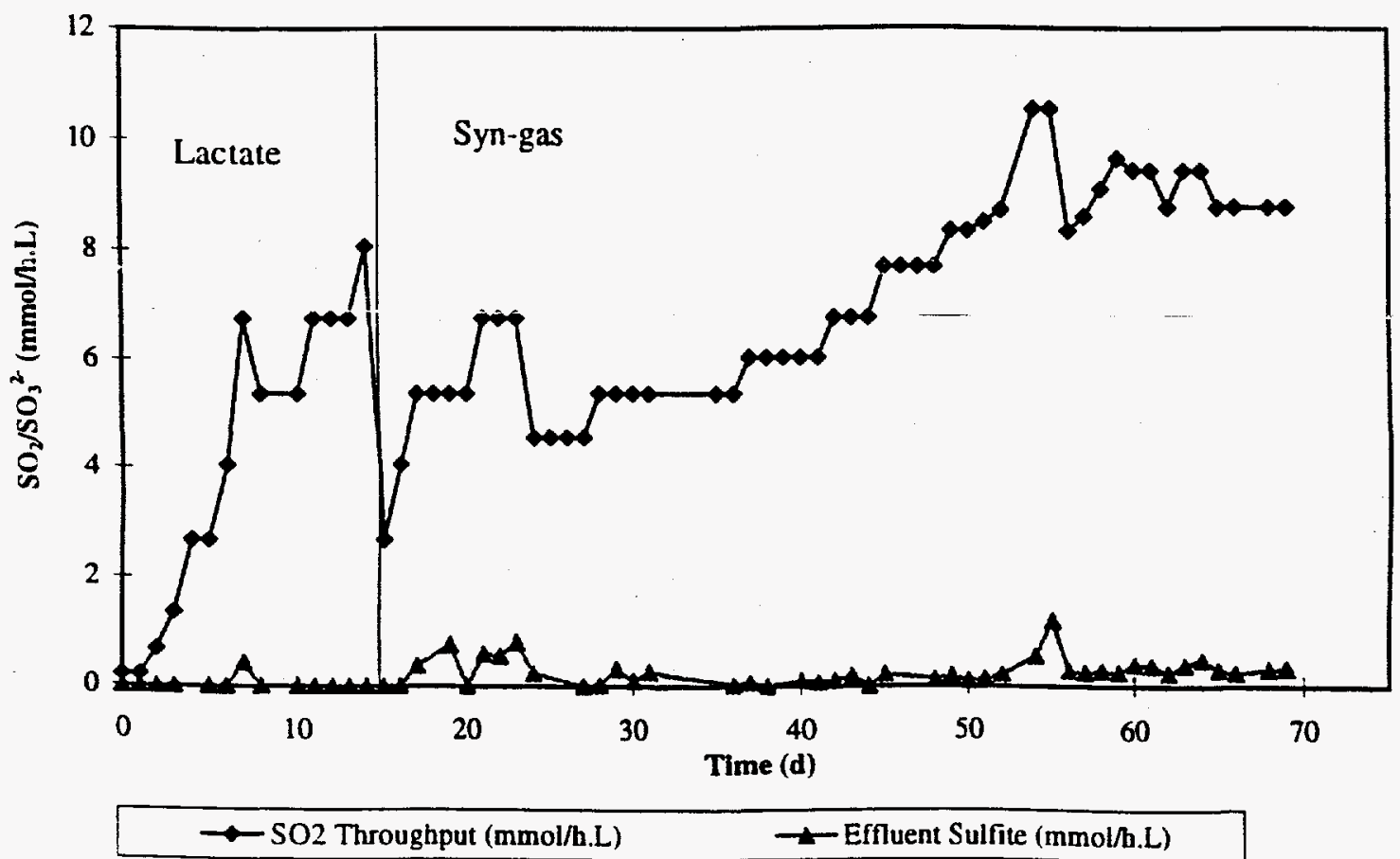

Figure 2. Sulfite conversion in a trickle-bed reactor with mixed SRB immobilized in BIO-SEP ${ }^{\text {TM }}$ beads. The liquid medium and gas mixture (syn-gas and $\mathrm{SO}_{2}$ ) were fed co-currently at the top of the reactor. 